\title{
The Main Insect Pests Attacking Wheat Plants and their Associated Predators in Sakha District, Kafr Elsheikh Governorate Awadalla, S. S. ${ }^{1}$; A. A. Ghanim ${ }^{1}$; F. E. Abd Allah ${ }^{2}$ and A. A. Abdel-Aziz ${ }^{2}$ \\ ${ }^{1}$ Economic Entomology Department, Faculty of Agriculture, Mansoura University, Egypt. \\ ${ }^{2}$ Plant Protection Research Institute, Agriculture Research Center, Dokki, Egypt.
}

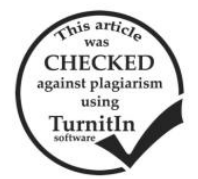

\section{ABSTRACT}

During the two seasons of study, the most abundant order was Hemiptera, included cereal aphids. English grain aphid, Sitobion avenae Fab. was the common species followed by Rhopalosiphum padi (L.), Schizaphis graminum (Rond.), Rhopalosiphium maidis (Fitch) and Diuraphis noxia Mordvilko (Aphididae), Empoasca spp. (Cicadellidae), Nilaparvata lugens (Delphacidae), Limothrips cerealium Haliday, Thrips tabaci Lindeman (Thripidae), Nezara viridula (L.), Eysarcoris inconspicuous (West.) (Pentatomidae), leaf-miner, Chromatomyia nigra (Meigen) (Diptra: Agromyzidae) were recorded in Egypt which caused a harmful losses of a green area of leaves, executed yield loss. Followed by Sphyrotheca spp. (order: Collombolla) and Silver Y moth, Phytometra gamma (Lepidoptera). In addition, eleven spots ladybird, Coccinella undecimpunctata (L.), was the most associated aphid specific predator, followed by others predators, Cydonia vicina isis Cr., Cydonia vicina nilotica Mul., Scymnus sp. and Rhyzobius litura Fab. (Coccinellidae), Paederus alfierii (Staphylinidae), Chrysoperla carnea (Steph.) (Chrysopidae), Metasyrphus corolla (Fab.) (Syrphidae) Orius sp. (Hemiptera).

\section{INTRODUCTION}

Wheat, Triticum aestivum L. is ranked the first cereal crop for human nutrition in Egypt and all over the world. Their offal's and straw were uses for animal nutrition. Egypt imports about the half of its wheat requirements. Shortage of wheat production is caused by harvest and store miss, uses and pests. Insect pests caused a great yield loss of wheat production, where, cereal aphid only, caused yield reduction estimated by up to $23 \%$ (Tantawi, 1985). Thus, protection and expansion the productions of wheat, will be highly appreciated, the cooperation between plant breeders, plant growers and plant protection specialists is highly needed to reach this aim. There are a change of abiotic factors of agriculture ecosystem followed by changes of their insect fauna. So, the study of this change of wheat insect fauna is the aim of this paper.

\section{MATERIALS AND METHODS}

The present study was carried out to survey the main insect pests attacking wheat plants and their associated predators at wheat program of Sakha Experimental Farm, Sakha Agriculture Station, Kafr ElSheik governorate, Egypt, during two successive seasons 2015/16 and 2016/17. Four replicates (plot dimensions: $3 \mathrm{~m} \times 3.5 \mathrm{~m} \log =10.5 \mathrm{~m}^{2}$ ) was sown by wheat variety Shandweel1 in optimum sowing date (Mid November), and visual count of all insects attacked ten tiller/ weekly beginning of second half of January to evaluate the main insect pests attacking wheat plants and their associated predators. Normal agriculture practices were carried out. No insecticides were used throughout the two studied seasons. All stages of main insect pests and associated predators were counted. The collected specimens were kept in vials containing $75 \%$ ethyl alcohol with some drops of glycerin to keep their tissues soft, and labeled for date. Identification according to key of Aphididae described by (Habib and El-Kady, 1961), (Helmi, 2011) and by Department of Classification in Plant Protection Research Institute, Agriculture Research Center, Cairo, Egypt.

\section{RESULTS AND DISCUSSION}

\section{The injurious Insect pests}

Mean numbers of insect pests/10 tiller were $364.64 \pm 108.39$ and $1270.5 \pm 98.48$ individuals in the first and the second seasons, respectively. These pests were classified to fourteen species belong to eight families and six orders, as follow:

Order: Hemiptera was the most abundant, with mean numbers $225.5 \pm 24.74$ and $580 \pm 34.58$ individuals, formed about $61.82 \%$ and $90.48 \%$ of mean counted insect pests in first and the second seasons, respectively. This order included seven species belong to three families. The numbers and ratio of these species were as follows:

\section{- Family Aphididae:}

Data presented in Table (1) recorded that aphids were the main insect pests on wheat plants. Aphids cause direct damage by feeding and indirect damage by transmission of viruses. On optimum conditions, aphid was a major squeeze of wheat production in Egypt. Wheat yield loss due to aphids' attacking was evaluated by up to $23 \%$ in Upper Egypt (Tantawi, 1985). In addition, the data reported that $R$. padi, $R$. maidis, $S$. graminum and $S$. avenae. were recorded as main cereal aphid species on wheat plants in Egypt agree with obtained of those El-Hariry (1979), Ghanim and El-Adl, (1983), Tantawi et al. (1986), Samad (2004), Sobhy et al. (2004), Slman, (2006) and Adly et al., (2006). Archer and Bynum (1993) and Attia and El-Kady (1988) were added the Russian wheat aphid, D. noxia. While, El-Heneidy (1994) found that $R$. padi was the most abundant aphid species in Egypt. El- Barro, (1992) recorded that $R$. padi was the most commonly trapped of cereal aphid species across South Australia, and M. dirhodium and Sitobion fragariae Walker were rarely trapped.

\section{English grain aphid, Sitobion avenae Fabricius}

The common species into the two seasons was $S$. avenae which attacked wheat plants beginning March to end-April causing of breakneck damage due to direct feeding on spikes. The mean number/10 tillers reached $158 \pm 16.71$ individuals, formed about $43.32 \%$ of mean insect pests in the first season, and $509 \pm 34.64$ individuals, formed about $79.4 \%$ in the second one. 
Green cereal- bug aphid, Schizaphis graminum Rondani Schizaphis graminum was appeared with a few numbers mixed with $S$. avenea beginning of March, feeding on high leaves and ears, causing of yield damage. Mean number/ 10 tillers was $32.5 \pm 3.79$ individuals, formed about $8.91 \%$ of mean insect pests in the first season and $11.5 \pm$ 0.85 individuals, formed about $1.79 \%$ in the second one.

Bird cherry-oat aphid, Rhopalosiphum padi Linnaeus

This species was appeared in a few numbers beginning of the two seasons, but quickly increased by midApril, where, attacked wheat plants during vegetable growth until yellow mature stage, causing harmful yield damage. Mean number/ 10 tillers was $4.75 \pm 1.25$ individuals, formed about $1.30 \%$ of mean insect pests in the first season, and $39.75 \pm 4.03$ individuals, formed about $6.20 \%$ in the second one.

\section{Corn leaf aphid, Rhopalosiphum maidis Fitch}

A few numbers with slight damage were appeared during the studied seasons. Mean number/ 10 tillers was $9.25 \pm 1.25$ individuals, formed about $2.54 \%$ of mean insect pests in the first season and $4.75 \pm 1.03$ individuals, formed about $0.74 \%$ in the second one.

Russian wheat aphid, Diuraphis noxia Mordvilko Russian wheat aphid, D. noxia was appeared in highly clad leaf of tillers, beginning of the season, during branching stage, synchronized with rain and low air temperature. Mean number/ 10 tillers was $9.25 \pm$ 1.25 individuals, formed about $2.54 \%$ of mean insect pests in the first season and $8.75 \pm 0.85$ individuals, formed about $1.37 \%$ in the second one.

\section{- Family: Cicadellidae}

Empoasca spp.

Empoasca spp. is a distributed insect pest to main crops all over much of the world. It was attacked wheat plants during all the season causing yield loss. Mean number/ 10 tillers in the first season was $4.75 \pm 0.63$ and $4.75 \pm 0.85$ individuals, formed 1.30 and $.74 \%$ of mean insect pests in the first and second seasons, respectively. The results was agree with obtained of those Sosa et al. (1988) who surveyed the cicadellidae populations in wheat in Argentina, and reported the main species were Syncharina punctatissima Signoret, Mendozellus dubius (Linnavuori) (Amplicephalus dubius), Atanus angatus, Empoasca sp., Tapajosa rubromarginata (Signoret), Agalliana ensigera (Oman), Exitianus obscurinervis (Stal), Amplicephalus obsoletus Linnavuori, and Stirellu picinus Ber.

\section{- Family: Delphacidae \\ Nilaparvata lugens (Stal)}

The appearance of plant hopper $N$. lugens in wheat field was not as much as leaf hopper species Empoasca spp. A mean number / 10 tillers in the first season was $7 \pm 0.41$ individuals, formed $1.92 \%$ of mean insect pests and $1.5 \pm$ 0.65 individuals, and formed $0.23 \%$ in the second one.

\section{- Family: Thripidae}

\section{Grain thrips, Limothrips cerealium Haliday}

Grain thrips, L. cerealium was attacked wheat plants during April synchronized with yellow mature stage of wheat plants feeding directly on ears causing a harmful damage to wheat yield. A mean number/ 10 tillers reached $73 \pm 0.41$ individuals in first season, formed $20.22 \%$ of mean insect pests, and $29.5 \pm 4.44$ individuals in the second season, and formed $4.60 \%$ of mean insect pests. This results was agree with those of Ghanim and El- Adl (1983), and Gentile and Trematerra (2004).

\section{Onion thrips, Thrips tabaci Linderman}

This species was attacked wheat plants during the season and feeding on hidden parts of plants. Mean recorded number/ 10 tillers was $59 \pm 12.49$ individuals in the first season, formed $16.38 \%$ of mean insect pests, and $16.75 \pm$ 3.77 individuals, and formed $2.61 \%$ in the second one. Similar results were obtained by Abdel-Aziz (2014)

\section{- Family: Pentatomidae}

Southern green stink bug, Nezara viridula Linnaeus

This species was found on wheat plants during two times, beginning the seasons and in the last third of the season, where, the air temperatures were optimum. This pest was a secondary pest on wheat plants, wherever, a few numbers were noted in both seasons/ 10 tillers was $1 \pm 0.48$ individuals in the first season, formed $0.27 \%$ of mean insect pests, and $2.5 \pm .64$ individuals, formed $0.39 \%$ in the second one.

Whites potted stink bug, Eysarcoris inconspicuous (Westwood)

This species was attacked wheat plants in the last of the season during earing stage on a few numbers with causing a slight damage. Mean bugs/ 10 tillers was $0.5 \pm$ 0.29 individuals, formed $0.14 \%$ of mean insect pests in the first season, and $0.75 \pm 0.48$ individuals, formed $0.12 \%$ in the second one.

\section{- Order: Diptra (Agromyzidae)}

The leaf-miner, Chromatomyia nigra (Meigen, 1830)

The leaf-miner, $C$. nigra was infested wheat leaves in two times, the first in beginning of the season. The few hatched larvae fed on upper surface epidermis of wheat leaf in blotches miners, and development to pupa in the miners to begging of March. The second stage flies appear beginning March and laying eggs were hatched during a few times to the major stage larva, caused of a bag damage to a green leaves area. Accordingly, highly decline of the yield were done. Mean numbers of life larva and pupa in blotches were $3.75 \pm 0.85$ individuals/ 10 tillers in the first season, with percentage $1.03 \%$ and $8.00 \pm 2.08$ individuals/ 10 tillers, percentage $1.25 \%$ in the second one.

\section{- Order: Collombolla}

Sphyrotheca spp. was attacked wheat plants beginning of February to end the season. Feed on strips upper the wheat leaves casing of dangerous harmful damage and yield loss. Their appearance was only during the second season. The mean number/10 tillers was $3.0 \pm 1.47$ individuals, with percentage $0.47 \%$.

\section{- Order: Lepidoptera}

Silver Y moth, Phytometra gamma (Linnaeus, 1758)

The larva was feed on leaves and ears some time caused a slight damage. A few numbers were appeared during the two seasons $0.5 \pm 0.29$ individuals with percentage $0.17 \%$ in the first season, and $0.5 \pm 0.29$ individuals with percentage $0.08 \%$ in the second one. 
Table 1. The main insect pest species infesting wheat plants and their percentages / 10 tillers, related to their orders in Kafr EL-Sheikh governorate during the two successive seasons 2015/16 and 2016/17.

\begin{tabular}{|c|c|c|c|c|}
\hline \multirow{2}{*}{ Injurious insect species } & \multicolumn{2}{|c|}{$2015 / 16$} & \multicolumn{2}{|c|}{ 2016/17 } \\
\hline & Mean \pm SE & $\%$ & Mean \pm SE & $\%$ \\
\hline Order: Homoptera & $158 \pm 16.71$ & 43.32 & & \\
\hline Sitobion avenea & $32.5 \pm 3.79$ & 8.91 & $509 \pm 34.64$ & 79.41 \\
\hline Schizaphis graminum & $4.75 \pm 1.25$ & 1.30 & $11.5 \pm 0.85$ & 1.79 \\
\hline Rhopalosiphum padi & $9.25 \pm 1.25$ & 254 & $39.75 \pm 4.03$ & 6.20 \\
\hline Rhopalosiphum maidis & & 2.54 & $4.75 \pm 1.03$ & 0.74 \\
\hline Diurahis noxia & $9.25 \pm 1.11$ & 2.54 & $8.75 \pm 0.85$ & 1.37 \\
\hline Empoasca spp. & $4.75 \pm 0.63$ & 1.30 & $4.75 \pm 0.85$ & 0.74 \\
\hline Nilaparvata lugens & $7 \pm 0.41$ & 1.92 & $1.5 \pm 0.65$ & 0.23 \\
\hline Total & $225.5 \pm 24.74$ & 61.82 & $580 \pm 34.58$ & 90.48 \\
\hline Order: Thysanoptera & $73.75 \pm 15.69$ & 20.22 & $29.5 \pm 4.44$ & 4.60 \\
\hline $\begin{array}{l}\text { Limothrips cerealium } \\
\text { Thrips tabaci }\end{array}$ & $59.75 \pm 12.49$ & 16.38 & $16.75 \pm 3.77$ & 2.61 \\
\hline Total & $133 \pm 28.19$ & 36.60 & $46.25 \pm 4.97$ & 7.21 \\
\hline Order: Hemiptera & $1 \pm 0.48$ & 0.27 & $2.5 \pm 0.64$ & 0.39 \\
\hline $\begin{array}{l}\text { Nezara viridula } \\
\text { Eysarcoris inconspicuous }\end{array}$ & $0.5 \pm 0.29$ & 0.14 & $0.75 \pm 0.48$ & 0.12 \\
\hline $\begin{array}{l}\text { Order: Diptra } \\
\text { Chromatomyia nigra }\end{array}$ & $3.75 \pm 0.85$ & 1.03 & $8.00 \pm 2.08$ & 1.25 \\
\hline $\begin{array}{l}\text { Order: Collombolla } \\
\text { Sphyrotheca sp. }\end{array}$ & 0.00 & 0.00 & $3.00 \pm 1.47$ & 0.47 \\
\hline $\begin{array}{l}\text { Order: Lepidoptera } \\
\text { Phytometra gamma }\end{array}$ & $0.5 \pm 0.29$ & 0.14 & $0.5 \pm 0.29$ & 0.08 \\
\hline General Total & $724.25 \pm 108.39$ & 100 & $1270.5 \pm 98.48$ & 100 \\
\hline
\end{tabular}

\section{The associated Predators.}

- Family: Coccinellidae

Eleven spot Ladybird, Coccinella undecimpunctata Linnaeus

Eleven spot ladybird $C$. undecimpunctata was the most associated aphid specific predator. Mean individuals/ 10 tillers was $4.5 \pm 0.65$ individuals in the first season formed $26.09 \%$ of mean predators, and $5 \pm$ 0.41 individuals formed $22.47 \%$ in the second one. The obtained data agree with those of Ghanim and El-Adl (1983), El- Heneidy and Attia (1989), Salem (2002), Samad (2004), El- Heneidy and Rizk (2004), Slman and Ahmed (2005), Slman (2006) recorded that $C$. undecimpunctata was the most specific aphid predator.

\section{Ladybirds, Cydonia vicina isis Mulsant}

A few numbers were noticed during the two seasons $0.5 \pm 0.29$ individuals/ 10 tillers in the first season formed $2.9 \%$ of mean predators, and $0.25 \pm 0.25$ individuals/ 10 tillers in the second one with percentage $1.12 \%$ of mean predators.

Ladybirds, Cydonia vicina nilotica Mulsant

A few numbers were recorded during the two seasons, where, $0.25 \pm 0.25$ individuals/ 10 tillers in the first season formed $1.45 \%$ and $0.25 \pm 0.29$ individuals/ 10 tillers in the second one with percentage $1.12 \%$ of mean predators. Ladybirds, Scymnus sp.

Scymnus sp. was one of coleopteran ladybirds associated aphids species on wheat plants. The noticed mean numbers in the first season were $1.75 \pm 0.48$ individuals with percentage $10.14 \%$ of mean predators in the first season, while, there were $2.5 \pm 0.29$ individuals with percentage $11.23 \%$ in the second one.

\section{Ladybirds, Rhyzobius litura Fabricius}

The recoded mean number in the first season was $2.5 \pm 0.29$ individuals, with percentage $14.49 \%$, while, this mean was $3 \pm 0.41$ individuals with percentage $13.49 \%$ in the second one.

The rove beetle, Paederus alfierii Koch

A few numbers was associated with wheat insects during the two studied seasons, where, recorded $2 \pm 0.41$ individuals with percentage $11.59 \%$ in the first season, and $2.25 \pm 0.63$ individuals with percentage $10.12 \%$ in the second one.

\section{- Family: Chrysopidae}

The green lacewing, Chrysoperla carnea (Stephens)

The mean recorded numbers/ 10 tillers were 3.25 \pm 0.48 individuals formed $18.84 \%$ in the first season of the mean recoded predators, and $3.25 \pm 0.63$ individuals formed $14.61 \%$ in the second one. These data agree with those of Salem and Mogahed (1990), Salem (2002), Samad (2004), El- Heneidy and Rizk (2004) and Yigit et al. (2007) they found that C. undecimpunctata and $C$. carnea were the most predominant predators of cereal aphids in wheat fields.

\section{- Family: Syrphidae}

The hover-fly Metasyrphus corollae (Fab.)

The mean recoded numbers/ 10 tillers were $1.5 \pm$ 0.50 individuals, formed $8.70 \%$ in the first season of the mean recoded predators, and $3 \pm 0.41$ individuals, formed $13.48 \%$ in the second one. The obtained results agreed with Samad (2004), El- Heneidy and Rizk (2004) and Yigit et al. (2007) recorded Syrphus spp. in the third predator's position after C. undecimpunctata and C. carnea. 
- Family: Hemiptera

Orius sp.

A few numbers of adults $1 \pm 0.41$ individuals/ 10 tillers was noticed, formed $5.80 \%$ of mean recoded predators in the first season, and $2.75 \pm 0.48$ individuals formed about $12.36 \%$ in the second one.
Data represented in Table (2) reported that $C$. undecimpunctata, $C$. carnea, and M. corollae were the most common specific aphid predators in wheat fields. These data agree with those obtained by Ghanim and El-Adl (1983), ElHeneidy and Attia (1989) and Salem and Mogahed (1990).

Table 2. The main insect predators and their percentages / 10 tillers associated wheat pests related to their orders in Kafr EL-Sheikh governorate during the two successive seasons 2015/16 and 2016/17.

\begin{tabular}{|c|c|c|c|c|}
\hline \multirow{2}{*}{ Beneficial insect species } & \multicolumn{2}{|c|}{$2015 / 16$} & \multicolumn{2}{|c|}{ 2015/17 } \\
\hline & Mean \pm SE & $\%$ & Mean \pm SE & $\%$ \\
\hline Order: Coleoptera & $4.5 \pm 0.65$ & 26.09 & $5 \pm 0.41$ & 22.47 \\
\hline Coccinella undecimpunctata & $0.5 \pm 0.29$ & $\begin{array}{c}20.09 \\
2.90\end{array}$ & $0.25 \pm 0.25$ & $\begin{array}{l}22.4 \\
1.12\end{array}$ \\
\hline Cydiona vicina isis & $0.25 \pm 0.25$ & 1.45 & $0.25 \pm 0.29$ & 1.12 \\
\hline & $1.75 \pm 0.48$ & 10.14 & $2.5 \pm 0.29$ & 11.23 \\
\hline Scymnus sp. & $2.5 \pm 0.29$ & 14.49 & $3 \pm 0.41$ & 13.49 \\
\hline $\begin{array}{l}\text { Rizobous litura } \\
\text { Paederus alfierii }\end{array}$ & $2 \pm 0.41$ & 11.59 & $2.25 \pm 0.63$ & 10.12 \\
\hline $\begin{array}{l}\text { Order: Neuroptera } \\
\text { Chrysoperla carnea }\end{array}$ & $3.25 \pm 0.48$ & 18.84 & $3.25 \pm 0.63$ & 14.61 \\
\hline $\begin{array}{l}\text { Order: Diptera } \\
\text { Metasyrphus corolla }\end{array}$ & $1.5 \pm 0.50$ & 8.70 & $3 \pm 0.41$ & 13.48 \\
\hline $\begin{array}{l}\text { Order: Hemiptera } \\
\text { Orius sp. }\end{array}$ & $1 \pm 0.41$ & 5.80 & $2.75 \pm 0.48$ & 12.36 \\
\hline Total & $17.25 \pm 1.79$ & 100 & $22.25 \pm 4.78$ & 100 \\
\hline
\end{tabular}

\section{REFERENCES}

Abdel-Aziz,A., A. (2014): Ecological and biological study on some insect pests infesting wheat crop and their associated predators. M.Sc. Thesis, Fac. Agric. Mansoura Univ., Egypt. 108 pp.

Adly, D.; A. H. El-Heneidy and M. M. El-Husseini (2006): Life tables of the aphid parasitoids species, Aphelinus albipodus (Hym: Aphelinidae) and its host the oat bird cherry aphid Rhopalosiphum padi (L.) (Homo: Aphididae) Egypt. Biol. Pest Cont., 16(1/2): 103-106.

Archer, T. L. and E. D. Bynum (1993): Ecology of the Russian wheat aphid (Homoptera: Aphididae) on dryland winter wheat in the Southern United States. J. Kans. Entomol., 84 (6): 1691-1694.

Attia, A.A. and E. M. El-Kady (1988): Diuraphis noxia Mordwilko, a recent addition to the aphid fauna of Egypt. Bull. Soc. ent. Egypte, 68, 259-266.

Barro, P. J. (1992): A survey of Rhopalosiphum padi (L.) (Hemiptera: Aphididae) and other wheat-infesting cereal aphids fling over South Australia in 1989.J. of the Australian Entom. Soc. 31(4):345-349.

El-Hariry, M. A. (1979): Biological and ecological studies on aphids attacking corn and wheat in Egypt. M. Sc. Thesis, Fac. Agric., Ain-Shams Univ.,Egypt. 213 pp.

EI-Heneidy, A. H. and A. A. Attia, (1989): Evaluation to the role of parasitoids and predators associated with aphids in wheat fields, Egypt. Bull. Soc. Entomol. Egypt. Economic Series 17: 137-147.

El-Heneidy, A. H. (1994): Efficacy of aphidophagous insects against aphids at wheat fields in Egypt. Egypt. J. Biol. Pest Control 4(2): 113-123.

El-Heneidy, A. H. and G. N. Rizk (2004): Comparative study of cereal aphid's species and their associated predators and parasitoids in two different wheat regions in Egypt. Egyptian $\mathrm{J}$. Bio. Pest Cont. 14(1): 217-224.
Gentile, P. and P. Trematerra (2004): Insect pests of hulled wheat and ecology of Sitotroga cerealella (Olivier): Tecnica Molitoria. Chiriotti Editori Spa, Pinerolo, Italy. 55(9):855-862.

Ghanim, A. A. and M. A. El-Adl (1983): Studies on the main insects inhabiting wheat fields at Mansoura district, Egypt. J. Agric. Sci. Mansoura Univ., 8(4):969-976.

Habib, A. and E.A. El-Kady (1961): The Aphididae of Egypt. Bull. Soc. Entomol. Egypt, 45: 1-137 pp.

Helmi, A. (2011): Identification of apterous viviparous of cereal aphids in Egypt (Hemiptera: Sternorrhyncha: Aphididae): Munis Entomology \& Zoology, 6 (1): 346-357.

Salem, S.A. and M.I. Mogahed (1990): Preliminary studies on the wheat aphids, Schizaphis graminum (Rondani) and Rhopalosiphum padi L. (Homoptera: Aphididae) at Menoufiya field wheat. Zagzig J. of Agric. Res., 1: 519, 1719-1724.

Salem, F. A. A. (2002): Studies on some natural enemies of some aphid's species at Kafr Elsheikh region M. Sc. Thesis, Fac. Agric. Kafr Elsheikh, Tanta univ., $130 \mathrm{pp}$.

Samad, S. S. M. (2004): Comparative study of cereal aphid species and their associated predators and parasitoids in two different wheat regions in Egypt. Egyptian J. Biol. Pest Control. 14(1): 183-191.

Slman, F. A. A. (2006): Incidence of cereal aphids and seasonal abundance of their parasitoids in wheat fields in Sohag (Upper Egypt) Assiut. Jour. of Agric. Sci., 37(2): 211-220.

Slman, F. A. A. and M. A. Ahmed (2005): Seasonal abundance of cereal aphids and ladybird beetle, Coccinella undecimpunctata (L.) on four cereal crops in South Egypt. Assiut J. Agric. Sci., 36(4): 205-215. 
Sobhy, H. M.; A. H. El-Heneidy; S. M. N. Abd ElWahed and W. Z. Mikhail (2004): Seasonal occurrence of the aphid parasitoid Aphidius colemoni Viereck (Hymenoptera: Aphididae) in Middle Delta. Egypt. Egypt. J. Biol. Pest Control. 14(1): 213-216.

Sosa, H. M; A. Rubiale; L. R. Sanchez; J.C. Otero and R. Audisio (1988): Survey of the cicadellids (Homoptera) from Cordoba, Argentina using coloured sticky traps. Revista de Ciencias Agropecuarias (Cordoba):6: 83-85.

Tantawi, A. M. (1985): Studies on wheat aphids in Egypt. II- Germplasm evaluation and crop loss assessment. RACHIS, 4(2): 26-27.
Tantawi, A. M.; G. E. Khidirand E. H. Ghanem (1986): The relative susceptibility of seven wheat varieties to infestation with the wheat aphids: Rhopalosiphium padi (L.) and Schizaphis graminum (Rond.): Ann. Agric. Soc. Fac. Agric., Ain Shams Uni., Cairo, Egypt, 31 (1): 777-785.

Yigit, A; E. Sertkaya and M. Tiryakioglu (2007): Population fluctuations of cereal aphids, Rhopalosiphum padi (L.) and Sitobion avenae (F.) (Homoptera: Aphididae) and their impact on crop loss parameters of wheat. Turkey, Türk. Entomol. Dreg., 31 (1): 21-34.

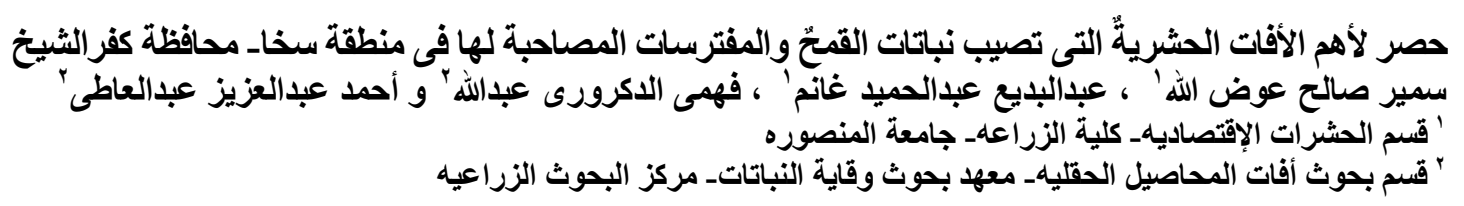

تم تسجيل أربعةٌ عشرةٌ نوعاً من الأفات الحشريه التى تصيب نباتات القمح، تتبع ثمان عائلات حشريه داخل ستةٌُ رثب

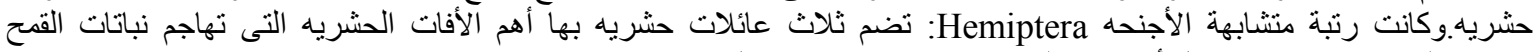

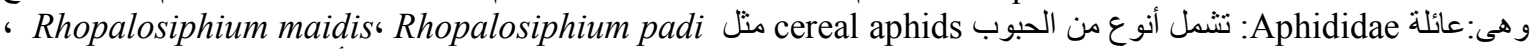

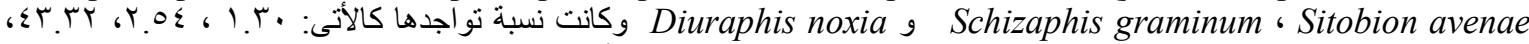

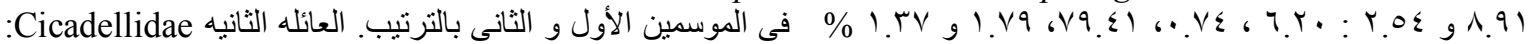

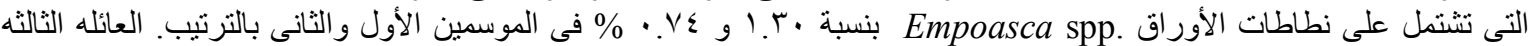

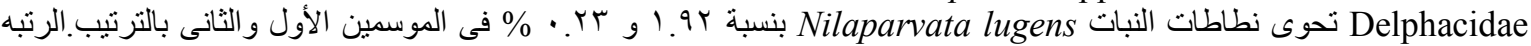

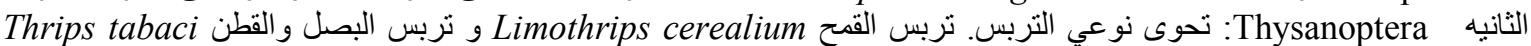

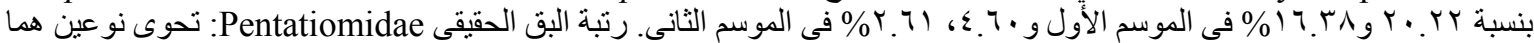

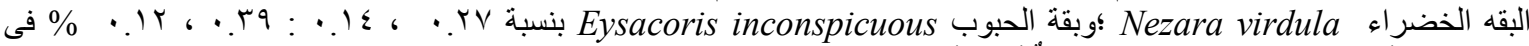

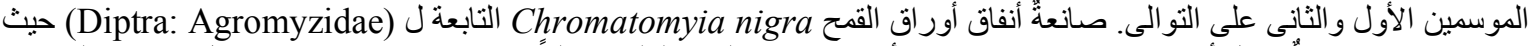

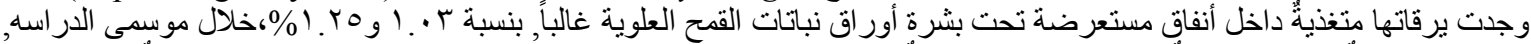

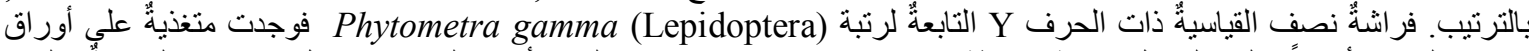

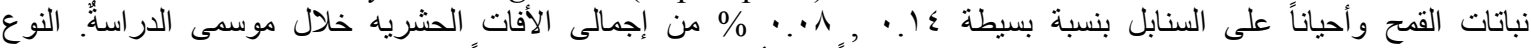
(Collombolla)

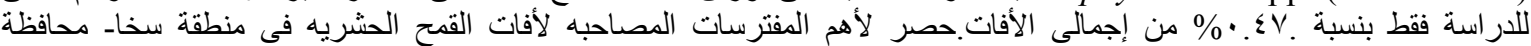

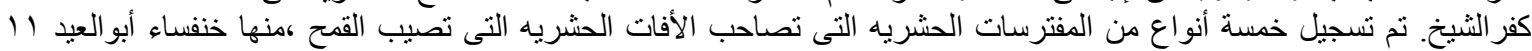

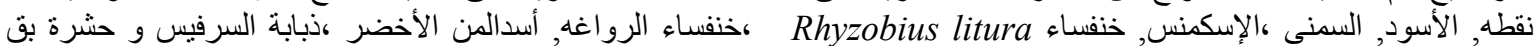
6 II Ourius spp.

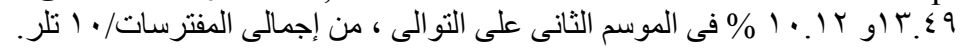

